This article was downloaded by: [New York University]

On: 16 April 2015, At: 09:42

Publisher: Routledge

Informa Ltd Registered in England and Wales Registered Number: 1072954

Registered office: Mortimer House, 37-41 Mortimer Street, London W1T

3J H, UK

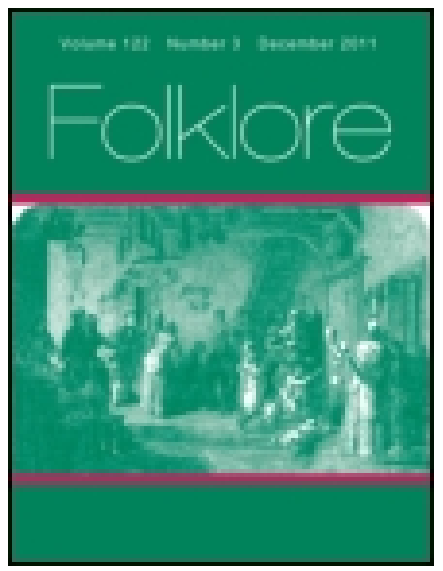

\title{
Folklore
}

Publication details, including instructions for authors and subscription information:

http:// www. tandfonline.com/loi/ rfol20

\section{The Provenience of certain Negro Folk- Tales}

Elsie Clews Parsons

Published online: 01 Feb 2012.

To cite this article: Elsie Clews Parsons (1917) The Provenience of certain Negro FolkTales, Folklore, 28:4, 408-414, DOI: 10.1080/ 0015587X.1917.9719009

To link to this article: http:/ / dx. doi.org/ 10.1080/ 0015587X. 1917.9719009

\section{PLEASE SCROLL DOWN FOR ARTICLE}

Taylor \& Francis makes every effort to ensure the accuracy of all the information (the "Content") contained in the publications on our platform. However, Taylor \& Francis, our agents, and our licensors make no representations or warranties whatsoever as to the accuracy, completeness, or suitability for any purpose of the Content. Any opinions and views expressed in this publication are the opinions and views of the authors, and are not the views of or endorsed by Taylor \& Francis. The accuracy of the Content should not be relied upon and should be independently verified with primary sources of information. Taylor and Francis shall not be liable for any losses, actions, claims, proceedings, demands, costs, expenses, damages, and other liabilities whatsoever or howsoever caused arising directly or indirectly in connection with, in relation to or arising out of the use of the Content.

This article may be used for research, teaching, and private study purposes. Any substantial or systematic reproduction, redistribution, reselling, loan, sub-licensing, systematic supply, or distribution in any form to anyone is 
expressly forbidden. Terms $\&$ Conditions of access and use can be found at http://www.tandfonline.com/page/terms-and-conditions 


\section{THE PROVENIENCE OF CERTAIN NEGRO FOLK-TALES.}

I.

\section{Playing Dead Troice ${ }^{1}$ in the Road.}

During the past year I have collected this tale among three separate Negro communities-among the American Negroes of North Carolina, ${ }^{2}$ among the English Negroes of the Bahamas, and among the Portuguese Negroes of the Cape Verde Islands living in Massachusetts and Rhode Island. The North Carolina tale is as follows :

Ol' rabbit an' fox went afishin. Ol' rabbit he was lazy an' he wouldn't fish none, an' ol' fox kep' atellin' him he'd better fish. An' he started home an' ol' rabbit tol' him to give him some fish. An' de ol' fox said he wouldn't give him none to save his life. De ol' rabbit asked ol' fox if he see a heap of rabbits layin' in de road would he pick 'em up ? $A n^{\prime}$ he said not 'less he see a heap of 'em.

'There is another and more familiar tale of playing dead once on the road, the tale of playing dead so as to be picked up by the carter and placed among his provisions. See Fortier, A., Louisiana Folk-Tales, p. 115; Mlem. Amer. Folk-Lore Soc., ii. (1895); and cp. Cosquin, E., Contes Populaires de Lorraine, ii. 159, 160. Paris. Superficially alike, the patterns of these two tales of playing dead on the road are quite dissimilar.

"See "Tales from Guilford County, North Carolina,"Jour. American FolkLore, April-June, 1917.

'A rationalising effort, it seems to me. In a Georgia tale (XV. Uncle Remus His Songs and His Sayings) the effort takes another turn. Brer Fox says the rabbit has been dead too long.

IIarris gives the shoe variant of this tale, too (XXII. Uncle Remus and His Friends). 
He run round den an' got in de path ahead of him an' lay down like he was dead. Ol' fox he come on an' kicked him outside of de road. An' ol' rabbit ran 'roun again an' got in de road an' lay down like he was dead. An' ol' fox said, "Hum I I pick you up." He turned in den an' lay him on a $\log$ aside of his fish an' goes back an' gets de oder one. When he got back again ol' rabbit took his fish an' was gone.

Of this tale I collected three variants on Andros Island in the Bahamas. The variant I got first and, I may note, the prevailing Andros variant differs little from the Carolinian variant. ${ }^{1}$

Boukee an' b'o' Rabbit make up ter go fishin'. Dey went fishin'. B'o Boukee ketch all de small fish an' b'o' Rabbit ketch all de big one. An' when dey come asho' b'o' Boukee say, "Share de fish," an' b'o' Rabbit say, "No, you share then. I only want de small one an' you take de beeg one." B'o' Rabbit done string up, an' he went befo'. He played dead in de road. Boukee said, "If I meet another rabbit like dis I go back an' get dat rabbit ; have two rabby an' a bunch of fish." B'o' Rabbit went befo' again an' played dead. B'o' Boukee said, "I'll go back an' get dat rabbit, an' I'll have two rabby an' a bunch of fish." $A n^{\prime}$ he went an' he meet no rabbit yet. $A n^{\prime}$ he come back, he meet no fish. So he went an' he cut off b'o' Rabbit an' he play dead. B'o' Rabbit said, "If I see anuder boukee like dis I'll go back an' get dat boukee an' I'll come back an' have two boukee an' a bunch of fish." B'o' Boukce went befo' an' play dead again. B'o' Rabbit said, "I'll go back and get dat boukce an' I'll cut dis one throat an' leave him to bleed till I come back." An' he went home. His wife ax him, "Where is de fish?" B'o' Rabbit tief (thieve) all de fish.

1 Of interest in this connection is the fact that during the American Revolu. tion many Carolinian Tories-United Empire Loyalists, they were calledmigrated with their slave households to the Bahamas. 


\section{Io The Provenience of certain Negro Folk-Tales.}

The only version I got of the second Andros Island variant was "spliced" into the tale of "In the Cow's belly." When Boukee jumps out of the cow and pretends the cleaners of the cow have thrown the maw over him, the hush money they give him are $£ 20$ and half the cow. " Boukee say, 'I got buy golden slippers fe me wife.' When he reach in de half way, he drop one of de slippers, an' he leave him in de road. ' B'o' Rabby gone an' pick up de slipper an' he ran t'rough de bush. B'o' Boukee put down his meat an' twenty poun' an' say, 'I got to go back fe de oder golden slipper.' Vwhen he reach back where he drop hees slipper, he foun' dat it was not dere: He started goin' home again. Vwhen he reach where he lef dis twenty poun' an' half of cow he foun' dat it was not dere. All dis time b'o' Rabby take dese t'ings an' gone home. Vwhen b'o' Boukee reach home hees wife say to him, 'You so crazy. It is b'o' Rabbit take dem same t'ings what you had.' An' de woman get arowin'."

The third Andros Island variant was written out and sent me by Rafalita Rolle of Mangrove Cay.

This was a man had three son, one name Tom and the other name Dick, one name Jack. His father ask them what trade they want. Tom say he want a shoe maker. He said, "Go." Dick said he want to be a minister. He said, "Go." Jack said he wanted to be a tief. He said that's what he want. $\mathrm{He}$ gave Jack ten dollars to go in the market to buy half a cow. Jack went in the market and call for the half of cow. Wiles' the man was cutting the cow, slip round to counter and took out ten dollars and mark ten on it and put it back. And mark ten on his one and put it back in his pocket and took the meat and start. The man call him back and ask him for the money. Jack said, "Man, I pay you." He said, "No, you aint pay mc." Jack start to cry and said he going home to tell his father. He said he is going to put Jack in jail. Jack said, "I had twenty dollars all mark 
ten and if I aint got all you get your ten." And he said, "If I got any in here mark ten you pay me." And when he look he find the ten dollars and Jack said, "If you don't pay I will report you." And man get scared and pay Jack one hundred poun.' And Jack carry it home. And his father told the king he got a boy will tief his life. And next day he buy one pair of gold slippers and send out Jack. One man was passing with a cart full of money. Jack put one the slipper in the road and hid. The man said, "What a pretty slipper!" $\mathrm{He}$ pass it an' Jack come out the bush and pick it up and run another road an' put it in the road and hide. The man said, "What a pretty slipper!" He jump down and he said he goin' back for the other one. When he was out of sight Jack run and take all the things and carried it home to his father.

It happened that the foregoing variant reached me when I was engaged in collecting tales which had already thrown light on my Bahama collection at large, tales from the Cape Verde Islands. It happened too that I had just heard the following Cape Verde Islands tale of

\section{The Master Thief. ${ }^{1}$}

José goes to a school of thieves. Within thirty days he knows more than the master. One day the master sends one of the best boys out to steal, for they had nothing to eat. The boy returned without anything. José said, "You better send me." "No, you don't know enough," said the master. They saw a man coming on the road with an ox on a rope. "I'm going to take that ox away from that man," said José. "If you are able to take that ox away from that man," said the master, "you'll

II omit the introduction. I omit, too, the continuation which consists of variations upon the pattern. I may say that the pattern in general of being robbed of property you leave to go and look for other things is well established in both the Cape Verde Islands and the Bahamas. 


\section{The Provenience of certain Negro Folk-Tales.}

prove to me you know all you need know." José went out, he took with him a silver shoe. He went ahead of the man with the ox, he threw the shoe in the road, he hid. The man saw the shoe. "Oh, what a pretty shoe," he said. "If it was a pair I'd take them to my daughter. (His daughter was getting married, he was taking the ox for the feast.) But I can't do anything with one shoe." Jose ran on ahead again, he dropped the shoe in the road. "Now there's a pair," said the man. "I'll tie my ox here, I'll go back to find the other shoe. I'll have a pair of pretty shoes for my daughter." José cut the rope tying the ox, he took the ox to his master. His master gave him his diploma. ${ }^{1}$

When the owner of the ox came back and found the ox gone, he thought the ox had chewed up the rope. "The ox has run off," he said, "I'll get my big, fat sheep." José covered himself with the hide of the ox and fixed its. horns on his head. He went down into a ravine where the man was coming with his sheep. There he lowed like an ox. "That's my ox," said the man. "You think you've escaped, do you? I'm going to tie my sheep and go and catch you." As the man passed through a grove of pulgeira, José came around and took the sheep.

The Norse tale of the Master Thief collected by Dasent ${ }^{2}$ and the Scotch tale collected by Campbell ${ }^{3}$ contain close parallels to this Cape Verde Islands tale. In the Norse tale the youth drops a pretty shoe with a silver buckle in the road. When the man with the ox sees the shoe a

\footnotetext{
1 In another version when the owner of the ox goes home with only one shoe he tells his wife about the mishap. Ile was' bringing her the shoes. "It was all on your account," he added. "Fool!" said she.
}

"Popular, Tales from the Norse,' p. 234-7. New York and Edinburgh. Other European variants have been recorded. See Köhler, R., in Orient and Occident, ii. (1864), 313; Schiefner, A., in Mitlanges Asiatigues, Bull.' de I Academie de St. Pltersbourg, vi. (1869-73), $18 \mathrm{r}$.

- Popular Tales of the West Highlands, xvii. d. London, 1890. 
second time he ties his ox and returns for the shoes to take the pair to his unamiable wife. To steal from the man his second ox the youth hangs himself to a tree thrice in succession. ${ }^{1}$ To determine whether or not it is witchcraft or actually three suicides the man ties up the ox and goes back to look for the other two hanging figures. To steal the third ox, the youth lures the man away by bellowing like an ox.

In the Scotch tale, Shifty Lad drops his own shoe in the way of the herd who was bringing a wether for a wedding. Subsequently, by ba-aing like the wether Shifty Lad purloins a kid, and after that, by bleating like a kid, a stot. ${ }^{2}$

Plainly the tale is European ${ }^{3}$ and a Portuguese variant must be inferred to be the origin of the Cape Verde Islands tale. That the tale was carried to the Southern States and to the Bahamas by Negroes from the African West Coast whcre it had been learned from Portuguese I have little or no doubt. 4 The only variants I have found besides those already noted may well have been borrowed also from the Portuguese. The following Amazonian Indian tale is close to the Carolinian variant and to one of the Bahama variants.

${ }^{2}$ Cp. Cosquin, ii. 276. Before this incident I had studying mistakenly concluded that the "playing dead" variant in the negro tales was a derivation of the "shoe" variant. It is plainly a variant of the man who hangs himself or who stands on his head (Cosquin, ii. 273, 276).

'Campluell, i. 235-7.

3 The source of the European Master Thief cycle I need not inquire into, but I note that in the Master Thief tale of Bengal the incident of the shoe in the road is given. Two gold-lace covered shoes are dropped in the road by the .elder thief. The younger thief picks up the second and ties his cow to return for the first (Lal Behari Day, Folk-Tales of Bengal, pp. 158.9. London, 1912).

- That the tale spread from the French in I.ouisiana is a tenable hypothesis, although, as far as I know, no French variant of the shoe pattern has been recorded. It is not only tenable, but improbable, that the third Andros Island variant was learned from Scotch sources in the Bahamas. 


\section{I4 The Provenience of certain Negro Folk-Tales.}

After some days the cotia became very thirsty. ... Just then an old man [a'black man . . . (mine the italics)] came along with a jar on his head. "I will see if I can get some water from that jar," thought the cotia. He ran ahead of the man, and lay down in the path. Presently the man came up. "Hullo!" said he, "here is a dead cotia!" and he shoved the animal to one side with his foot, and went on. As soon as he was out of sight, the cotia jumped up, and ran on through the woods until he was in front of the man again; then he lay down in the path, as before. "Hullo!" said the man coming up, "here's another dead cotial" and he kicked the animal out of his path. Again the cotia ran ahead of the man, and lay down in the path. "Hullo !" said the man, "this makes three dead cotias that I have seen; now if I see another one I will go back and get them all." Once more the cotia repeated his trick. "Hullo I" said the man, "here's another dead cotia! Now I will go back and get the others, and carry all four home." With that, he put down his jar, and went to look for the other dead cotias. As soon as he was gone, the cotia jumped up and thrust his head into the jar. ${ }^{1}$

There is an analogous Soudanese tale of a man carrying. a basket of fowls to market who is fooled by a fox. ${ }^{2}$ This tale was collected in a country where there was a lively traffic in slaves. That the tale may have travelled herefrom the Portuguese West Coast appears not at all improbable. The cycle of the Master Thief is known on the West Coast. Lederbogen recorded it among the Dvala of the Cameroons. $^{3}$ In the Dvala tale, however, although the cattle stealing incident is given the playing dead pattern. is entirely lost.

Elsie Ciews Parsons.

'Smith, II. II., Brazil, p. 552. New York, 1879. Also p. 555.

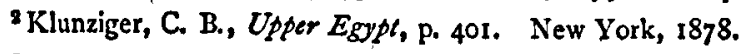

Sour. African Soc, xiii. (Oct., 1904), p. 64. 